\title{
Controlling variegated thistle in East Coast North Island hill-country
}

\author{
K.N. TOZER, R.M. GREENFIELD, M.B. DODD, T.K. JAMES and C.A. CAMERON \\ Ruakura Research Centre, AgResearch, Private Bag 3123 Hamilton, New Zealand
}

Katherine.tozer@agresearch.co.nz

\begin{abstract}
Variegated thistle can dominate north-facing slopes on North Island East Coast hill-country reducing pasture production and livestock carrying capacity. On a hillcountry sheep and beef property near Gisborne, the herbicides 2,4-D + clopyralid were applied in earlyMay by knapsack in combination with a June aerial application of 2,4-D ester. This was more effective than a single June aerial application of 2,4-D ester in reducing the abundance of variegated thistle and enabling grasses from the seedbank to colonise the bare ground in the herbicide-treated patches. Mixtures of grasses, legumes and herbs, oversown onto bare patches previously occupied by thistle plants, did not establish on a north-facing slope. While they did establish on a south-facing slope, the sown species did not persist, most likely due to selective grazing. To establish competitive pasture, natural germination from the seedbank may be less risky than oversowing seed into thistle patches, if desirable species are present in the seedbank.
\end{abstract}

Keywords: Silybum marianum, weed control, herbicide, competition, competitive pasture species

\section{Introduction}

Variegated thistle (Silybum marianum) can severely reduce pasture productivity (Chambreau \& MacLaren 2007). It is an annual that predominantly germinates throughout autumn (Khan et al. 2009) and flowers in late-spring producing over 6000 seeds/plant (Sindel 1991). The seeds are heavy (about $20 \mathrm{mg} / \mathrm{seed}$ ), fall near the parent plant and can remain viable for at least 9 years in the soil (Roche 1991). The thistle can grow up to $2.5 \mathrm{~m}$ tall and form dense thickets on a range of aspects and slopes, suppressing the growth of desirable pasture species. The base of the flowers, stems and leaves have many sharp spines that promote livestock avoidance, affecting both production (lower utilisation of forage) and management (impeding livestock and vehicular movement) (Chambreau \& MacLaren 2007).

In other situations, variegated thistle is considered highly productive and profitable. It is grown as a medicinal plant because it produces silymarin, which is extensively used in the pharmaceutical industry (Martin et al. 2006; Alemardan et al. 2013). As such, its potential use in New Zealand as a horticultural crop has been explored. However, negative impacts of variegated thistle, as described above, have made it a declared pest plant in some regions such as the Gisborne District and, therefore, growing it for its medicinal properties is not an option.

Where variegated thistle plants form dense thickets and crowd out other pasture species in New Zealand East Coast hill-country, there may be little pasture cover remaining over summer after the thistle produces seeds and dies. This leads to conditions that favour thistle establishment in successive autumns; the bare ground can be easily recolonised from the seed in the localised soil seedbank. This cycle can lead to self-perpetuating thistle patches that gradually spread if control methods are not deployed (Roche 1991).

A range of control methods have been explored. Biocontrol has been largely unsuccessful (Bruzzese 1996). Goats have been successfully used in Australia and elsewhere (Davidson 1990; Stanley et al. 2000). Chemical herbicides can be effective (Glue \& Matthews 1957; Dellow 1996), but are costly and can damage desirable pasture legumes or produce resistant populations of the thistle (Harrington et al. 2011). Further, chemical control alone without pasture improvement is of little use (Glue \& Matthews 1957).

Control of variegated thistle using pasture management is a potential option, particularly during autumn when thistle seeds germinate, as they are particularly vulnerable to shading during establishment (Pook 1983). To develop a dense sward, it may be necessary to introduce seed of competitive pasture species into hill-country pastures where variegated thistle has become endemic, especially in old thistle patches where much bare ground is present over summer. A dense sward may be produced from species that are productive and grow vigorously, such as perennial ryegrass (Lolium perenne), plantain (Plantago lanceolata) and prairie grass (Bromus willdenowii) or that are considered to be less productive, but form a dense mat, such as browntop (Agrostis capillaris) or some fescue species (Festuca spp.). Whatever the choice, consideration must be given to their suitability for the environment in which they are to be grown. Additionally, the timing of herbicide application can be manipulated to increase desirable pasture cover and obtain greater control of variegated thistle (Robertson 1955; Duncan 1963). Spraying the thistle with herbicide 


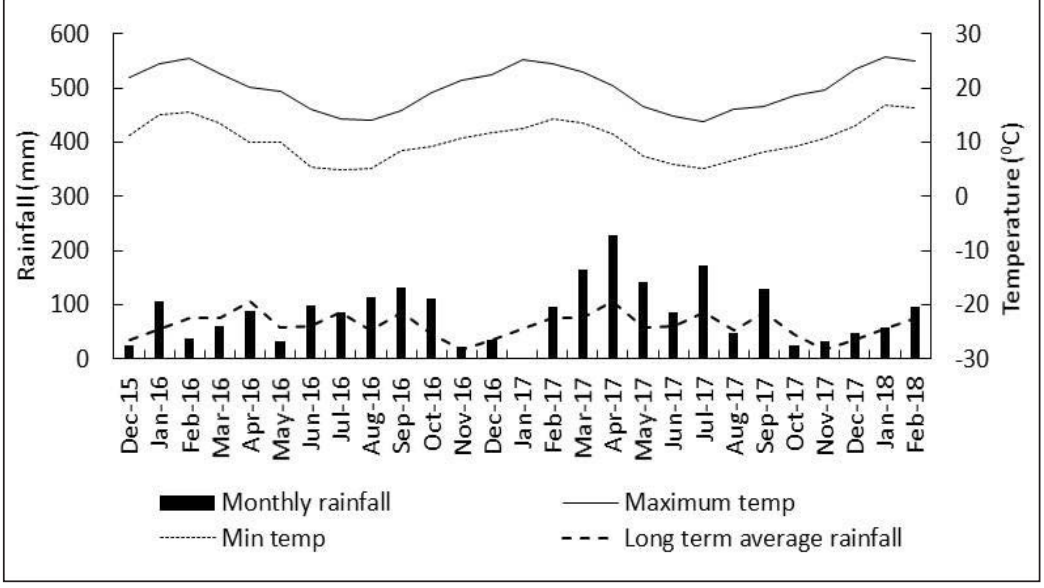

Figure 1
Rainfall (bars), average maximum and minimum temperature and 20 -year average (1995-2015) rainfall for Tangihanga Station. above average in summer 2017-2018 (203 versus 169 long-term).

Soil test results were not available for the specific experimental sites, but the most recent farm soil test results (September 2014) were: $\mathrm{pH}=5.6$, Olsen $\mathrm{P}=$ $14 \mathrm{mg} / \mathrm{kg}$, QT K = 7.2, QT $\mathrm{Ca}=5.9$, QT $\mathrm{Mg}=17.2$, Sulphate $\mathrm{S}=2.6 \mathrm{mg} / \mathrm{kg}$.

\section{Thistle patch characterisation (2016) - Experiment 1}

To determine to what extent variegated thistle could replace pasture species

early in autumn should remove them from the sward when they are smaller and have had less opportunity to crowd out other pasture species. However, this may necessitate multiple herbicide applications if the germination period is prolonged; thistle that germinates and establishes after the first application may still pose a major threat to pasture productivity. Another potential benefit of earlier application is that a greater range of herbicides can be used on the smaller thistle plants, including ingredients which are less harmful to legumes.

To investigate control options for variegated thistle in East Coast hill-country, a range of treatments were compared from 2016 to 2018. This included different combinations of competitive or mat-forming pasture species and variation in the timing and type of herbicide application, aiming to increase pasture cover and reduce thistle populations. The hypothesis tested was that a greater cover of competitive pasture species in autumn (by either introduction of pasture species and/ or earlier application of herbicide to manipulate the sward composition) will reduce thistle populations and thereby improve the pasture botanical composition.

\section{Methods}

\section{Site}

The study sites were on Tangihanga Station near Gisborne (38 33' 25" S177 53' 17' E), a 2000 ha mixed sheep and cattle breeding and finishing hillcountry unit. It is a summer-dry environment with a 20 year average summer rainfall (December to February) of $169 \mathrm{~mm}$ and average annual rainfall of $1166 \mathrm{~mm}$ (based on interpolation of the NIWA CliFlo database, Figure 1). Rainfall was below average in autumn 2016 (183 versus $240 \mathrm{~mm}$ long-term), below average in summer 2016-2017 (132 versus $169 \mathrm{~mm}$ long-term) and and form dense patches, the botanical composition of three large (each $>1.0$ ha), randomly chosen, thistle patches on northerly aspects in each of six paddocks ( 3 patches/paddock), were assessed using a point quadrat method, on 20th December 2016. The northerly aspect was chosen as this was where the variegated thistle was most prevalent and formed the densest patches. In each patch, the identity of the plant species (at ground level) was recorded at $1 \mathrm{~m}$ intervals along a $10 \mathrm{~m}$ chain transect (Power 1991). This was done for 10 parallel transects separated by $1.5 \mathrm{~m}$, giving a total of 100 points in each patch.

\section{Productive pasture species establishment (2016- 2017) - Experiment 2}

The establishment success of three hand-broadcast multi-species mixes was determined on a moderatelysloped $\left(15-25^{\circ}\right)$ northerly aspect in one paddock and southerly aspect in another. Treatments comprised three mixes (legume only, and two combinations of grasses, legumes and herbs) and an unsown resident control (Table 1). The species included were subterranean clover (Trifolium subterraneum), white clover (Trifolium repens), balansa clover (Trifolium michelianum), grazing brome (Bromus stamineus), perennial ryegrass, cocksfoot (Dactylis glomerata), plantain and chicory (Cichorium intybus). The sown species were used at the same seed rate in all three treatments (Table 1). Treatments were established in $5 \times 5 \mathrm{~m}$ plots in a randomised complete block with four replicate blocks positioned down the hillside.

Paddocks were grazed by Coopworth ewes to a residual of about $1500 \mathrm{~kg} \mathrm{DM} / \mathrm{ha}$ preceding aerial spraying with paraquat on 7 th May ( $200 \mathrm{~g}$ /ha a.i. in 200 $\mathrm{L}$ water). This achieved sward suppression with grass browned-off and about 1000-1200 kg DM/ha of wilted 
cover remaining at sowing.

Seed was hand-broadcast on 12th and 13th May 2016 on the southerly and northerly aspects, respectively. The southerly aspect site was trampled by 1300 ewes on 12th May, with the mob run 10 times across the paddock section in which the plots were located. The soil of the northerly aspect site was too dry for trampling so this was postponed until 30th May after $12 \mathrm{~mm}$ of rain using the same procedure as for the southerly aspect site. Slug bait was applied at the time of sowing and also on 19th July at a rate of about $20 \mathrm{~kg} / \mathrm{ha}(18 \mathrm{~g} / \mathrm{kg}$ metaldehyde).

Seedlings were counted on 18th July 2016, in ten random $15 \times 10 \mathrm{~cm}$ quadrats in each plot. Herbage production was estimated using 20 rising plate meter readings per plot (Farmworks Plate Meter F200). The plate meter was calibrated using the industry recommended all-year calibration: Compressed pasture height x $140+500$ (Thomson \& Blackwell 1999; Lile et al. 2001; Anon 2008). The proportion of each sown species in total herbage dry matter was assessed on 17th October and 6th December 2016 and 22nd March 2017 , in twenty $40 \times 25 \mathrm{~cm}$ quadrats in each plot using the BOTANAL method, a dry weight ranking method involving visual estimation of the first, second and third most dominant species in the sward (Tothill et al. 1992). Pre-determined multipliers based on multiple pasture cuts were then used to estimate the contribution of each species to total herbage dry matter (Jones \& Hargreaves 1979; Tothill et al. 1992).

Productive pasture species and thistle control (20162017) - Experiment 3

A site was established on the northerly aspect (in the same paddock as Experiment 2) to test whether the oversown mixes could suppress the establishment of variegated thistle. Old thistle patches (aerial sprayed with a helicopter in June-July 2015) were randomly

Table 1 Species sown on a northerly and southerly aspect in three hand-broadcast multi-species mixes on a hill-country property near Gisborne in Experiments 2 and 3.

\begin{tabular}{lcccc}
\hline Species & $\begin{array}{c}\text { Sowing } \\
\text { rate (kg/ha) }\end{array}$ & $\begin{array}{r}\text { Control* }^{*} \\
\text { species }\end{array}$ & $\begin{array}{c}4 \\
\text { species }\end{array}$ & $\begin{array}{c}7 \\
\text { species }\end{array}$ \\
\hline Subterranean & & & & \\
${\text { or white clover }{ }^{* *}}^{*}$ & 9 & $X$ & $X$ & $X$ \\
Balansa clover & 6 & $X$ & $X$ & $X$ \\
Grazing brome & 20 & & $X$ & $X$ \\
Perennial ryegrass & 16 & & & $X$ \\
Cocksfoot & 4 & & $X$ & $X$ \\
Plantain & 2 & & & $X$ \\
Chicory & 2 & & & $X$ \\
\hline
\end{tabular}

${ }^{*}$ Control: resident pasture. ${ }^{* \star} A$ late flowering subterranean cultivar was sown on the North aspect and white clover on the south aspect. identified and seed mixes were hand-broadcast within these patches on 13th May 2016, after all live thistle plants were removed by hand roguing. Thistle patches were identified by the presence of pieces of old thistle stem lying on the ground.

Treatments, comprising the same four and sevenspecies mixes (Table 1) and resident pasture as a control, were established in a randomised complete block with seven replicate blocks positioned down the hillside within seven randomly selected old thistle patches. Plots were $5 \times 5 \mathrm{~m}$. The same establishment and measurement protocols (including the same dates) were followed as for the pasture establishment study.

\section{Integrated control (2017-2018) - Experiment 4}

Combinations of herbicide application and oversowing with competitive pasture species to control variegated thistle were compared. The three treatments were 'early application' (2,4-D + clopyralid applied by knapsack), 'early application + oversowing' (glyphosate by knapsack + oversowing a fescue-browntop mix) and 'late application' (2,4-D ester by aerial application, Table 2 ). The whole property (2000 ha) progressively received a late aerial application of 2,4-D ester $(2 \mathrm{~L} / \mathrm{ha})$, from 29th June 2016 till the end of July 2017. Hence herbicide was applied twice in the early application treatments (May and July) but only once in the late application treatment (July). The oversown pasture mix was Duraturf Traditional ${ }^{\mathrm{TM}}$, comprising $5 \%$ by weight of browntop (Agrostis capillaris) and the remainder equal portions of creeping fescue (Festuca rubra subsp. rubra) and Chewings fescue (Festuca rubra subsp. commutata). This mix was chosen as it grows in low fertility conditions, is not highly palatable for livestock and thus less likely to be selectively grazed, and forms a thick mat of grass to help suppress thistle emergence. A germination test of the mix at $25^{\circ} \mathrm{C}$ yielded a germination percentage of $64 \%$ of seed after 19 days.

Treatments were applied in six of the paddocks used to characterise thistle patches (Experiment 1). Three large (>1.0 ha) thistle patches were randomly selected on northerly aspects in each paddock, and treatments applied in a $6 \times 6 \mathrm{~m}$ plot in the centre of each patch. The design was a randomised complete block, with six replicate paddocks.

Herbicide was applied on 8th May 2017 (as per Table 2) and the Duraturf Traditional ${ }^{\mathrm{TM}}$ seed mix was oversown at a rate of $40 \mathrm{~g} / \mathrm{m}^{2}(400 \mathrm{~kg} / \mathrm{ha}) 17$ days later on 24th May, allowing a 2 week gap to ensure that sown grass seedlings were not affected by the herbicides. After hand-broadcasting, plots were trampled by foot and a heavy chain dragged multiple times $(>10)$ across each plot to increase seed-soil contact.

On 8th May 2017 at the time of the early herbicide application, variegated thistle plants were counted 
in sixteen $25 \times 40 \mathrm{~cm}$ quadrats in each plot and ground cover of the thistle, grasses, legumes and broadleaf weeds visually assessed. On 28th June 2017 (51 days after herbicide was applied in the 'early application' treatments), three measurements of treatment effectiveness were made: variegated thistle plant population density, percentage control (a score estimating the percentage of thistle visually affected by the herbicide), and the percentage cover of bare ground. Further thistle population density and ground cover assessments were undertaken on 13th September 2017 and 20th March 2018.

\section{Results}

Thistle patch characterisation (2016) - Experiment 1 When assessed on 20th December 2016, thistle plants were senescent; thickets of stems were present with shrivelled leaves at the base of the dense thistle stands. Grasses other than perennial ryegrass (e.g., browntop and Rytidosperma spp.) were the most abundant component in thistle patches, averaging $51 \%$ of ground cover (range: $11-84 \%$ ) then variegated thistle plants averaging $44 \%$ (range $11-77 \%$ ). Perennial ryegrass averaged $4 \%$ (range $0-10 \%$ ) and bare ground $1 \%$ (range $0-10 \%)$.

Productive pasture species establishment (20162017) - Experiment 2

Oversown forage grasses, legumes and herbs sown in late-autumn 2016 did not establish on the northfacing aspect; there was no difference $(\mathrm{P}>0.05$, data not shown) in seedling densities of oversown pasture species between any of the treatments and the unsown control in July 2016 or in their ground cover in October 2016, after which time measurements were discontinued.

On the south aspect, seedling densities of perennial ryegrass, cocksfoot, plantain and chicory were higher in the seven-species mix than in the control in July
2016, with 55 total sown seedling $/ \mathrm{m}^{2}(\mathrm{P}<0.05$, Table 3$)$. The percentage of white clover as a proportion of total dry matter was greater in the seven-species mix than in the control in October 2016, as was the percentage composition of plantain in December $2016(\mathrm{P}<0.05$, Table 3). No other differences between sown treatments and the unsown control were detected in October 2016 or in March 2017. By March 2017, unsown low palatability grasses, predominantly browntop and Rytidosperma spp., comprised $61 \%$ of the total dry matter.

Available dry matter averaged 2400 and 1510 $\mathrm{kg} \mathrm{DM} / \mathrm{ha}$ in September 2016 and December 2016, respectively, and there was no difference in pasture production between any of the sown treatments and the unsown control $(\mathrm{P}>0.05)$. Cattle were in the paddock during the March 2017 assessment when the available pasture dry matter was lower in the seven-species mix than in the unsown control (1360 versus $1570 \mathrm{~kg} \mathrm{DM} /$ ha, $\mathrm{P}<0.05)$.

\section{Productive pasture species and thistle control (2016- 2017) - Experiment 3}

Oversown pasture species established in the thistle patches, but did not persist beyond the first year and were thus unable to suppress variegated thistle. Seedling densities of balansa clover, plantain and total sown species were greater in the four and sevenspecies mix than in the unsown control in July 2016 (Table 4). Total sown seedlings averaged 21 plants/ $\mathrm{m}^{2}$ in the oversown treatments, but only 2 plants $/ \mathrm{m}^{2}$ in the unsown control, where some ryegrass seedlings emerged from the seedbank (Table 4). By October 2016, the percentage of perennial ryegrass in total dry matter was over four-fold greater in the seven-species mix than in the unsown control, and the total percentage of sown species was over five-fold greater in the sevenspecies mix compared to the unsown control. However, by the following autumn (March 2017), there were

Table 2 Herbicides applied to control variegated thistle on a hill-country property near Gisborne in autumn and winter 2017 in Experiment 4. Pasture Guard herbicide was applied at a rate of $2 \mathrm{~L} / \mathrm{ha}$.

\begin{tabular}{|c|c|c|c|c|c|c|}
\hline \multirow{2}{*}{$\begin{array}{l}\text { Product name } \\
\text { (active ingredient) }\end{array}$} & \multirow[t]{2}{*}{ Method } & \multirow{2}{*}{$\begin{array}{l}\text { Water rate } \\
\text { (L/ha) }\end{array}$} & \multirow[t]{2}{*}{ Applied } & \multicolumn{3}{|c|}{ Treatment } \\
\hline & & & & Early application & $\begin{array}{l}\text { Early application } \\
\text { + oversowing }\end{array}$ & Late application \\
\hline $\begin{array}{l}\text { Pasture Kleen } 680 \\
(2500 \mathrm{~g} 2,4-\mathrm{D} \text { ester/ha) } \\
+ \text { Versatill } 300 \\
(100 \mathrm{~g} \text { clopyralid/ha) }\end{array}$ & Knapsack & 150 & 8 May & $x$ & & \\
\hline $\begin{array}{l}\text { Weedmaster TS540 } \\
\text { (200 g glyphosate/ha) }\end{array}$ & Knapsack & 150 & 8 May & & $x$ & \\
\hline 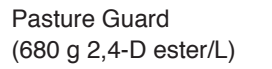 & Aerial & 100 & July & $\mathrm{x}$ & $x$ & $x$ \\
\hline
\end{tabular}


no differences in species composition between the oversown treatments and the unsown control $(\mathrm{P}>0.05$, data not shown).

Although all variegated thistle seedlings were removed from the plots at the time of sowing in March 2016 , new thistle seedlings averaged $1 \%$ of total dry matter in July 2016, 5\% in October 2016 and 3\% in March 2017. There was no difference between the oversown treatments and the unsown control in the ground cover of variegated thistle.

\section{Integrated control (2017-2018) - Experiment 4}

In May 2017, before herbicide application, the plant density of variegated thistle seedlings was similar in all three treatments, averaging $27 / \mathrm{m}^{2}$. On 28th June 2017 (51 days after herbicide was applied in both 'early' treatments), variegated thistle plants comprised $<2 \%$ of total ground cover in the early application treatments, but $89 \%$ of total ground cover in the 'late application' treatment $(\mathrm{P}<0.001$, Table 5). In contrast, bare ground was greater in the early application treatments $(25$ and $67 \%$ ) than the late application treatment (2\%) in which thistle plants had not yet been sprayed $(\mathrm{P}<0.001$, Table $5)$. The thistle control score also indicated that the early application had been effective, with an average of $98 \%$ of plants affected in the early treatments.

By September 2017, herbicide applications had reduced thistle densities to less than one plant $/ \mathrm{m}^{2}$ in both early application treatments and four plants $/ \mathrm{m}^{2}$ in the late application treatment. By the following autumn (2018), new variegated thistle plants had emerged and there was no difference between treatments in thistle population density, averaging six seedlings $/ \mathrm{m}^{2}$ and occupying $14 \%$ of total ground cover $(\mathrm{P}>0.05$, Table 5$)$.

There was no effect of oversowing the fescuebrowntop seed mix on the botanical composition of the sward. There was no difference between the earlyspray and early-spray + oversowing in fescue-browntop ground cover (data not shown) or total grass ground cover on any of the assessment dates $(\mathrm{P}>0.05$, Table 5$)$.

By September 2017, grass species that emerged from the seedbank had replaced the thistle in the early application treatments and occupied the bare ground, averaging $71 \%$ of total ground cover in the early

Table 3 Seedling establishment and percentage of total dry matter of individual and total sown species in swards oversown with two, four and seven-species mixes and in the unsown resident pasture (control) on a south aspect of the hill-country property near Gisborne in Experiment 2. Means in bold are greater than those in the control $(\mathrm{P}<0.05)$.

\begin{tabular}{|c|c|c|c|c|c|c|c|c|}
\hline Measurement & Month & Species & Control & 2-species & 4-species & 7-species & SED & F prob \\
\hline \multirow[t]{6}{*}{ Establishment (seedlings $/ \mathrm{m}^{2}$ ) } & July 2016 & White Clover & 12 & 24 & 24 & 25 & 9.5 & NS \\
\hline & & Plantain & 0 & 0 & 0 & 12 & 2.3 & 0.002 \\
\hline & & Chicory & 0 & 0 & 0 & 4 & 0.2 & $<.001$ \\
\hline & & Cocksfoot & 0 & 0 & 0 & 2 & 0.3 & $<.001$ \\
\hline & & Perennial ryegrass & 0 & 0 & 0 & 13 & 2.3 & 0.001 \\
\hline & & Total sown species & 12 & 24 & 29 & 55 & 10.1 & 0.013 \\
\hline \multirow[t]{2}{*}{ Composition (\% of total DM) } & October 2016 & White clover & 5 & 12 & 13 & 20 & 3.7 & 0.015 \\
\hline & December 2016 & Plantain & 0.1 & 0.5 & 1.3 & 3.2 & 0.86 & 0.024 \\
\hline
\end{tabular}

NS = not significant

Table 4 Seedling establishment and percentage in total dry matter of oversown four and seven-species mixes in variegated thistle patches on the hill-country property near Gisborne on a southerly aspect in Experiment 3 . The control was unsown pasture. Means in bold are greater than those in the unsown control $(P<0.05)$.

\begin{tabular}{|c|c|c|c|c|c|c|c|}
\hline Measurement & Date & Species & Control & 4-species & 7-species & SED & F prob \\
\hline \multirow[t]{3}{*}{ Establishment seedlings $/ \mathrm{m}^{2}$} & July 2016 & Balansa clover & 0 & 6 & 5 & 2.1 & 0.027 \\
\hline & & Plantain & 0 & 8 & 8 & 2.8 & 0.024 \\
\hline & & Total sown species & 2 & 21 & 20 & 6.8 & 0.024 \\
\hline \multirow[t]{5}{*}{ Composition (\% of total DM) } & October 2016 & Perennial ryegrass & 10 & 15 & 44 & 12.6 & 0.034 \\
\hline & & Subterranean clover & 0 & 3 & 1 & 0.6 & $<.001$ \\
\hline & & Unsown grasses & 84 & 74 & 42 & 12.5 & 0.011 \\
\hline & & Plantain & 0 & 4 & 6 & 1.1 & $<.001$ \\
\hline & & Total sown species & 10 & 22 & 51 & 12.8 & 0.017 \\
\hline
\end{tabular}


application treatments and only $21 \%$ of total ground cover in the late application treatment $(\mathrm{P}<0.001$, Table 5 ). Of the grasses, perennial ryegrass was the dominant species, and to a lesser extent browntop, sweet vernal (Anthoxanthum odoratum), Microlaena and Rytidosperma species. Grasses continued to dominate the swards, averaging $64 \%$ of total ground cover in the early application treatments, but only $31 \%$ of total ground cover in the late application treatment in March $2018(\mathrm{P}<0.05$, Table 5). There was a trend towards greater broadleaf weed content and more bare ground in the late application than in the early application treatment, measured in March 2018. However, differences between treatments were not significant due to the high variability between the six replicate paddocks $(\mathrm{P}>0.05)$. Variability between paddocks was exacerbated by livestock impacts. For example, in two of the paddocks, livestock trampling and pugging of early application treatment plots were noted in June and September 2017.

\section{Discussion}

In the absence of effective management, variegated thistle formed dense patches by late autumn, after which other pasture species were crowded out until the thistle plants senesced in late summer. This was demonstrated in Table 5, which shows that thistle ground cover was $87 \%$ by May and $89 \%$ by June 2017, but only approximately $50 \%$ of ground cover in December when the plants were senescent and the grass cover had increased. Despite the strong competitive pressure from the variegated thistle population, some perennial ryegrass plants were able to grow and were present as thistle plants died. These grasses appear to be important as they were able to set seed while protected by the variegated thistle plants and this seed was observed to be critical to regenerating pasture. The severe impact of variegated thistle on pasture production emphasises the importance of preventing its establishment, whether through judicious use of herbicide or other means, such as maintaining a competitive pasture sward and dense cover to reduce thistle establishment.

Table $5 \quad$ Variegated thistle density and ground cover of variegated thistle, grasses, broadleaved weeds and bare ground in three herbicide application treatments on the hill-country property near Gisborne in Experiment 4. Early application: knapsack applied 2,4-D + clopyralid in May 2017 and Early application + oversow knapsack applied glyphosate + oversowing (hand broad-casting) of a fescue-browntop mix on 8th May 2017. Late application: aerial application of herbicide to the whole property in July 2017. Means in bold are different to those in the unsown control $(P<0.05)$.

\begin{tabular}{|c|c|c|c|c|c|c|}
\hline Measurement & Date & Late application & Early application & $\begin{array}{l}\text { Early application } \\
+ \text { Oversow }\end{array}$ & SED & F prob \\
\hline \multicolumn{7}{|c|}{ Variegated thistle density } \\
\hline \multirow[t]{3}{*}{ Thistles/m² } & May 2017 & 34 & 20 & 28 & 5.7 & NS \\
\hline & Sept 2017 & 4 & $<1$ & $<1$ & 1.4 & 0.04 \\
\hline & March 2018 & 4 & 5 & 9 & 2.5 & NS \\
\hline Control score & June 2017 & 0 & 96 & 99 & 2.0 & $<0.001$ \\
\hline \multicolumn{7}{|c|}{ Ground cover (\%) } \\
\hline \multirow[t]{4}{*}{ Thistle } & May 2017 & 87 & 79 & 70 & 7.1 & NS \\
\hline & June 2017 & 89 & 2 & $<1$ & 3.3 & $<0.001$ \\
\hline & Sept 2017 & 49 & $<1$ & $<1$ & 13.7 & 0.007 \\
\hline & March 2018 & 16 & 8 & 17 & 8.8 & NS \\
\hline \multirow[t]{3}{*}{ Grasses } & May 2017 & 13 & 21 & 30 & 7.1 & NS \\
\hline & Sept 2017 & 21 & 76 & 66 & 9.9 & $<0.001$ \\
\hline & March 2018 & 31 & 66 & 62 & 11.9 & 0.031 \\
\hline \multirow[t]{3}{*}{ Weeds } & May 2017 & 0 & 0 & 0 & - & - \\
\hline & Sept 2017 & $<1$ & 0 & 0 & - & - \\
\hline & March 2018 & 29 & 13 & 9 & 11.2 & NS \\
\hline \multirow[t]{4}{*}{ Bare ground } & May 2017 & 0 & 0 & 0 & - & - \\
\hline & June 2017 & 2 & 25 & 67 & 7.8 & $<0.001$ \\
\hline & Sept 2017 & 29 & 24 & 34 & 9.6 & NS \\
\hline & March 2018 & 24 & 12 & 11 & 6.2 & NS \\
\hline
\end{tabular}

$\mathrm{NS}=$ not significant 
The studies undertaken provided limited evidence for the hypothesis that a greater cover of competitive pasture species in autumn will reduce thistle populations. Oversowing competitive pasture species was not successful. The poor persistence of the oversown mix on both north and south aspects where the oversown species established, was most likely due to selective grazing by sheep. The operator observed on several measurement dates that the sown species on the south aspect were defoliated by the livestock to a much greater extent than the unsown control and surrounding pasture, which is consistent with lower herbage production in the seven-species mix than the unsown control in March 2017. Productive pasture species such as perennial ryegrass, cocksfoot and legumes have a higher nutritive value and are more palatable than species such as browntop (Fulkerson et al. 2007; Lambert \& Litherland 2000) that were present at the field site where it formed a thick mat with a high proportion of dead material of low nutritive value. Based on these results and the problem of selective grazing, oversowing desirable pasture species into larger patches ( $>1$ ha) of variegated thistle after herbicide application is unlikely to succeed.

The approach of oversowing the fescue-browntop mix was also unsuccessful, since it did not establish. This may be due to other species in the seedbank being more competitive and being better able to establish at lower temperatures associated with a late autumn sowing date (e.g. perennial ryegrass, Wright et al. 1978). Earlier application of herbicide (i.e. in April) and oversowing of browntop when soil temperatures were higher may have been more successful; further studies on timing of herbicide application and oversowing are required.

Both the early and late herbicide application treatments successfully reduced the variegated thistle densities in the following autumn but did not eliminate them totally. This lack of difference between treatments in the low thistle densities emphasises the need for repeat treatment of infested areas over subsequent years given that variegated thistle seed can remain viable in the seedbank for many years. Some studies have found that seeds last for 10 years in the soil, although seed viability declines rapidly over the first few years (Bruzzese 1996). This indicates that surveillance and removal of survivors in the first few years after a thistle control program is particularly important.

Although the integrated control study did not provide evidence for the hypothesis with respect to oversowing competitive pasture species and reducing thistle populations, some of the herbicide treatments applied successfully improved botanical composition. At the time of designing the study, the intent was to apply a control treatment of untreated variegated thistle in addition to the two knapsack applied herbicide treatments. Variegated thistle infestations over the farm were particularly severe in autumn 2016 (covering up to an estimated $15 \%$ of individual paddocks) and it was concluded that the negative impact on the farm would be too great if the six paddocks in which the plots were established had to forgo an aerial application of herbicide. Thus the control became 'aerial herbicide application only', and it was the difference in timing between the aerial and knapsack applied treatments that had the greatest impact on botanical composition.

The major difference between the treatments was that grasses recolonised the sward to a greater extent in the patches after early applications of herbicide. So by September, the bare ground had been replaced by grasses which resulted in three times as much grass cover produced from an early than a late application. This is not surprising given that the thistle plants were a month younger and smaller and temperatures were warmer at the time of the early application treatment. This is in contrast to the late application of herbicide in June, when little grass was present in the sward and $89 \%$ of the ground cover comprised thistle and temperatures were cooler. Warmer temperatures would facilitate greater growth of grass from the seedbank (in the early application treatment receiving glyphosate) and from the seedbank and existing grass plants (in the early application + oversow treatment where selective herbicide was used). The principle of working with the desirable pasture species in the soil seedbank has also been investigated by Maxwell et al. (2014) in South Island hill-country. They demonstrated how adventive clovers contributed more than oversown clovers to the total pasture biomass. The species emerging from the seedbank are more likely to be adapted ecotypes than those of oversown species (Wedderburn et al. 1996), which will contribute to their establishment success and persistence. In a recent study located on the same property as reported here, James \& Tozer (2018) found sufficient seed of perennial ryegrass and legumes in the soil seed bank to regenerate pasture after removal of variegated thistle.

There was large variability between replicate paddocks, which affected the statistical significance of the results. In a number of early application plots, livestock trampling and pugging could have impeded grass growth. It appears that the livestock (bull beef) were attracted by the thistle-free sprayed plot areas in the dense large patches and congregated there. By contrast, in the late application treatment, the entire thistle patch inside and outside the plot area was similarly affected by the herbicide, and there was no visual evidence of stock congregating in the late application treatment plot areas. This observation demonstrates how there can be unintended consequences of applying treatments at 
a plot scale within a paddock, leading to interactions with livestock that can override the effect of the actual treatment. These interactions must be taken into account when interpreting results. Despite this difficulty, the impact of the herbicide on the pasture composition was statistically evident.

\section{Conclusions}

There are frequent summer droughts and variable autumn rains in North Island East Coast hill-country, which makes control of variegated thistle difficult. Given the failure of the oversowing treatments, but the significant herbicide effects, it is concluded that timing of application of herbicide to whole thistle patches should be prioritised and that oversowing of patches is risky due to establishment failure or selective grazing. A better strategy may simply be allowing the seedbank or existing grasses in the sward to fill the gaps by applying herbicide earlier when thistle rosettes are small. Further, repeat chemical application over several years, taking into account the need to avoid the evolution of herbicide resistance in the thistles, will likely be required given that the variegated thistle seedbank is persistent.

\section{ACKNOWLEDGEMENTS}

Thanks to AgResearch and Ravensdown Limited for funding this research. The Wi Pere Trust and Gavin Sheath facilitated hosting the research at Tangihanga, and Tim Rhodes and Brent Gallagher provided valuable on-farm management support. Mike Trolove (AgResearch) provided technical support in the field. Thanks also to the reviewers (Kerry Harrington and Graeme Bourdót) for their constructive comments on the draft manuscript.

\section{REFERENCES}

Alemardan, A.; Karkanis, A.: Salehi, R. 2013. Breeding objectives and selection criteria for milk thistle [Silybum marianum (L.) gaertn.] improvement. Notulae Botanicae Horti Agrobotanici Cluj-Napoca 41: 340-347.

Anon. 2008. DairyNZ FarmFact 1-15. Using the Rising Plate Meter (RPM). DairyNZ, New Zealand, pp. 4.

Bruzzese, E. 1996. Ecology of Cirsium vulgare and Silybum marianum in relation to biological control. Plant Protection Quarterly 11: 245-249.

Chambreau, D.; MacLaren, P.A. 2007. Got milk thistle? An adaptive management approach to eradicating milk thistle on dairies in King County, Washington State. General Technical Report Pacific Northwest Research Station, USDA Forest Service 694. pp. 8384.

Davidson, S. 1990. Goats help eliminate thistles. Rural Research 147: 16-19.
Dellow, J.J. 1996. Herbicide techniques for thistle management. Plant Protection Quarterly 11: 276277.

Duncan, A.A. 1963. Weeds of the Wanganui district. Proceedings of the 16th New Zealand Weed Control Conference 16: 13-15.

Fulkerson, W.J.; Neal, J.S.; Clark, C.F.; Horadagoda, A.; Nandra, K.S.; Barchia, I. 2007. Nutritive value of forage species grown in the warm temperate climate of Australia for dairy cows: Grasses and legumes. Livestock Science 107: 253-264.

Glue, D.I.; Matthews, L.J. 1957. Weed identification. Variegated thistle. New Zealand Journal of Agriculture 95: 547.

Harrington, K.C.; Beskow, W.B.; Hodgson, J. 2011. Recovery and viability of seeds ingested by goats. New Zealand Plant Protection 64: 75-80.

James, T.K.; Tozer, K.N. 2018. Variegated thistle plant population density not correlated with soil bank seed density. New Zealand Plant Protection 71: 51-56.

Jones, R.M.; Hargreaves, J.N.G. 1979. Improvements to the dry-weight-rank method for measuring botanical composition. Grass and Forage Science 34: 181-189.

Khan, M.A.; Blackshaw, R.E.; Marwat, K.B. 2009. Biology of milk thistle (Silybum marianum) and the management options for growers in north-western Pakistan. Weed Biology and Management 9: 99-105. Lambert, M.G.; Litherland, A.J. 2000. A practitioner's guide to pasture quality. Proceedings of the New Zealand Grassland Association 62: 111-115.

Lile, J.A.; Blackwell, M.B.; Thomson, N.A.; Penno, J.W.; Macdonald, K.A.; Nicholas, P.K.; Lancaster, J.A.S.; Coulter, M. 2001. Practical use of the rising plate meter (RPM) on New Zealand dairy farms. Proceedings of the New Zealand Grassland Association 63: 159-164.

Martin, R.J.; Lauren, D.R.; Smith, W.A.; Jensen, D.J.; Deo, B.; Douglas, J.A. 2006. Factors influencing silymarin content and composition in variegated thistle (Silybum marianum). New Zealand Journal of Crop and Horticultural Science 34: 239-245.

Maxwell, T.M.R.; Moir, J.L.; Edwards, G.R. 2014. Productivity and seedling recruitment of naturalised annual clovers versus sown clovers Trifolium repens and Trifolium subterraneum. Proceedings of the New Zealand Grassland Association 76: 117-124.

Pook, E.W. 1983. The effect of shade on the growth of variegated thistle (Silybum marianum L.) and cotton thistle (Onopordum sp.). Weed Research 23: 11-17.

Power, I. 1991. Pasture species transects. Technical Report Number 3. Whatawhata Research Centre, MAFTech. pp. 15.

Robertson, R.D. 1955. Progress in the suppression of noxious weeds in Wanganui county. Proceedings of 
the 8th New Zealand Weed Control Conference: $65-$ 68.

Roche, C. 1991. Milk thistle (Silybum marianum (L.) Gaertn.). Pacific Northwest Cooperative Extension Publication (PNW382).

Sindel, B.M. 1991. A review of the ecology and control of thistles in Australia. Weed Research 31: 189-201.

Stanley, D.F.; Holst, P.J.; Allan, C.J. 2000. The effect of sheep and goat grazing on variegated thistle (Silybum marianum) populations in annual pastures. Plant Protection Quarterly 15: 116-118.

Thomson, N.A.; Blackwell, M.B. 1999. The new pasture assessment model. Proceedings of the South Island Dairy Event. pp. 60-67.
Tothill, J.C.; Hargreaves, J.N.G.; Jones, R.M.; McDonald, C.K. 1992. BOTANAL: a comprehensive sampling procedure for estimating pasture yield and composition. I. Field sampling. CSIRO, Division of Tropical Crops and Pastures, St. Lucia, Brisbane, Australia.

Wedderburn, M.E.; Adam, K.D.; Greaves, L.A.; Carter, J.L. 1996. Effect of oversown ryegrass (Lolium perenne) and white clover (Trifolium repens) on the genetic structure of New Zealand hill pastures. New Zealand Journal of Agricultural Research 39: 41-52.

Wright, D.L.; Blaser, R.E.; Woodruff, J.M. 1978. Seedling emergence as related to temperature and moisture tension 1. Agronomy Journal 70: 709-712. 
